\title{
Relationship between gastro-intestinal complaints and endotoxaemia, cytokine release and acute phase reaction during and after a long-distance triathlon in highly trained men
}

Citation for published version (APA):

Jeukendrup, A. E., Vet-Joop, K., Sturk, A., Stegen, J. H. C. H., Senden, J. M. G., \& Saris, W. H. M. (2000). Relationship between gastro-intestinal complaints and endotoxaemia, cytokine release and acute phase reaction during and after a long-distance triathlon in highly trained men. Clinical Science, 98(1), 4755. https://doi.org/10.1042/cs0980047

Document status and date:

Published: 01/01/2000

DOI:

$10.1042 / \operatorname{cs} 0980047$

Document Version:

Publisher's PDF, also known as Version of record

Please check the document version of this publication:

- A submitted manuscript is the version of the article upon submission and before peer-review. There can be important differences between the submitted version and the official published version of record. People interested in the research are advised to contact the author for the final version of the publication, or visit the DOI to the publisher's website.

- The final author version and the galley proof are versions of the publication after peer review.

- The final published version features the final layout of the paper including the volume, issue and page numbers.

Link to publication

\footnotetext{
General rights rights.

- You may freely distribute the URL identifying the publication in the public portal. please follow below link for the End User Agreement:

www.umlib.nl/taverne-license

Take down policy

If you believe that this document breaches copyright please contact us at:

repository@maastrichtuniversity.nl

providing details and we will investigate your claim.
}

Copyright and moral rights for the publications made accessible in the public portal are retained by the authors and/or other copyright owners and it is a condition of accessing publications that users recognise and abide by the legal requirements associated with these

- Users may download and print one copy of any publication from the public portal for the purpose of private study or research.

- You may not further distribute the material or use it for any profit-making activity or commercial gain

If the publication is distributed under the terms of Article $25 \mathrm{fa}$ of the Dutch Copyright Act, indicated by the "Taverne" license above, 


\title{
Relationship between gastro-intestinal complaints and endotoxaemia, cytokine release and the acute-phase reaction during and after a long-distance triathlon in highly trained men
}

\author{
A. E. JEUKENDRUP*, K. VET-JOOP†, A. STURK†, J. H. J. C. STEGEN*, J. SENDEN*, \\ W. H. M. SARIS* and A. J. M. WAGENMAKERS* \\ ${ }^{*}$ Department of Human Biology, Maastricht University, P.0. Box 616, 6200 MD Maastricht, The Netherlands, and \\ †Department of Clinical Chemistry, Leiden University Medical Center, P.0. Box 9600, 2300 RC Leiden, The Netherlands
}

A

\begin{abstract}
The aim of the present study was to establish whether gastro-intestinal (GI) complaints observed during and after ultra-endurance exercise are related to gut ischaemia-associated leakage of endotoxins [lipopolysaccharide (LPS)] into the circulation and associated cytokine production. Therefore we collected blood samples from 29 athletes before, immediately after, and I, 2 and $16 \mathrm{~h}$ after a long-distance triathlon for measurement of LPS, tumour necrosis factor- $\alpha$ and interleukin-6 (IL-6). As the cytokine response would trigger an acute-phase response, characteristic variables of these responses were also measured, along with creatine kinase (CK) to obtain an indicator of muscle damage. There was a high incidence ( $93 \%$ of all participants) of Gl symptoms; $45 \%$ reported severe complaints and $7 \%$ of the participants abandoned the race because of severe $\mathrm{Gl}$ distress. Mild endotoxaemia $(5-15 \mathrm{pg} / \mathrm{ml}$ ) was evident in $68 \%$ of the athletes immediately after the race, as also indicated by a reduction in IgG anti-LPS levels. In addition, we observed production of IL-6 (27-fold increase immediately after the race), leading to an acutephase response (20-fold increase in C-reactive protein and $12 \%$ decrease in pre-albumin $16 \mathrm{~h}$ after the race). The extent of endotoxaemia was not correlated with the GI complaints or the IL-6 response, but did show a correlation with the elevation in C-reactive protein $\left(r_{\mathrm{s}} 0.389\right.$; $P=0.037)$. Creatine kinase levels were increased significantly immediately post-race, and increased further in the follow-up period. Creatine kinase levels did not correlate with those of either IL-6 or C-reactive protein. It is therefore concluded that LPS does enter the circulation after ultra-endurance exercise and may, together with muscle damage, be responsible for the increased cytokine response and hence $\mathrm{Gl}$ complaints in these athletes.
\end{abstract}

\section{INTRODUCTION}

Prolonged exercise at high intensity leads to a quantitative redistribution of blood flow, i.e. flow to the exercising muscles is increased in order to supply oxygen and substrates. In addition, during intense exercise the blood flow to the skin is increased to facilitate heat dissipation.
As a consequence, blood flow to central tissues (gut and liver) is reduced during exercise [1,2]. During maximal exercise in humans, blood flow to the gut is reduced by about $80 \%$ [3]. Exercise in the heat leads to an extra loss of total body water and a greater decrease in plasma volume, with further reduction in blood flow to the gut $[4,5]$. A similar redistribution of blood flow is seen in

Key words: anti-lipopolysaccharide, endotoxins, exercise, gastro-intestinal complaints, immunology, lipopolysaccharide, triathlon. Abbreviations: CK, creatine kinase; CRP, C-reactive protein; GI, gastro-intestinal; IL-6, interleukin-6; LAL, Limulus amoebocyte lysate; LPS, lipopolysaccharide(s); TNF- $\alpha$, tumour necrosis factor- $\alpha$.

Correspondence: Dr Asker Jeukendrup, School of Sport and Exercise Sciences, University of Birmingham, Edgbaston, Birmingham B15 2TT, U.K. (e-mail A.E.Jeukendrup@bham.ac.uk). 
patients with major trauma and/or sepsis and various forms of shock [6]. In this situation, a serious underperfusion of the gut often leads to shock-induced mucosal damage and invasion of Gram-negative intestinal bacteria and/or their toxic constituents (endotoxins) into the blood circulation [7]. Endotoxins are highly toxic lipopolysaccharides (LPS) of the outer cell wall of Gramnegative bacteria. Increased circulating LPS levels in patients lead to various symptoms, such as fever, shivering, dizziness, nausea, various gastro-intestinal (GI) complaints such as vomiting and diarrhoea, and ultimately sepsis [8]. Such symptoms are also frequently reported by ultra-endurance athletes, in particular GI problems such as stomach cramps or stomach ache, intestinal cramps and diarrhoea [9-11]. The prevalence of such symptoms has been reported to be $30-50 \%$ among marathon runners [12-14]. Marathon runners occasionally develop serious gut complaints (blood loss in the faeces) in the hours following a marathon, which may be due to increased intestinal permeability [15]. Despite their high prevalence, the aetiology of these GI complaints in endurance athletes is still incompletely understood.

Not only might decreased splanchnic blood flow lead to ischaemic damage to the intestinal wall, but there may also be thermal and mechanical damage to the mucosal layer of the gut. Gram-negative bacteria, present in the gut, may then penetrate the mucosal layer and enter the lymph nodes in the submucosal tissues. This may lead to the entry of LPS into the portal vein and, under extreme conditions, even into the main circulation. Indeed, endotoxaemia after strenuous ultra-endurance exercise has been reported in some studies [16-18], although this finding was not consistent [19-21].

LPS are a major trigger in vivo for the host immune response via induction of the cytokine network. The cytokine tumour necrosis factor- $\alpha$ (TNF- $\alpha$ ) is presumed to be the central inflammatory mediator [22]. TNF- $\alpha$ is produced by macrophages and monocytes. It stimulates the production of other cytokines by monocytes and other cells, including endothelial cells. Other pro-inflammatory cytokines include interleukin-1 (IL-1) and IL-6 [23]. TNF- $\alpha$, IL-1 and IL-6 have many biological effects, including the triggering of the acute-phase response $[24,25]$. This involves substantial changes in the plasma concentrations of many proteins in response to bodily harm, e.g. an increased inflammatory or surgical situation. Both increases and decreases in plasma protein concentrations, the so-called positive and negative acutephase responses, occur due to changes in their rate of synthesis in the liver. IL-6 induces the full spectrum of the acute-phase reaction, whereas IL- 1 and TNF- $\alpha$ lead to only a partial reaction $[24,25]$. Pre-albumin and C-reactive protein (CRP) are good examples of negative and positive acute-phase reactants respectively.

The first aim of the present study was to investigate whether endotoxaemia occurs in the $16 \mathrm{~h}$ after a longdistance triathlon. We also measured IgG anti-LPS antibody concentrations as an indicator of LPS leakage, as such antibodies are expected to decrease over a more prolonged time period than potential LPS appearance in the circulation, due to the formation and subsequent clearance of LPS-anti-LPS complexes. Furthermore, decreases in anti-LPS may also be seen when LPS is produced only locally (e.g. in the gut and portal vein), i.e. without appearing in the systemic circulation. We also measured the cytokines TNF- $\alpha$ and IL- 6 as possible mediators of LPS-induced effects, and CRP and prealbumin as indicators of the acute-phase reaction. A second aim of our investigation was to study the relationship between GI complaints and the measured indirect markers of the gut barrier function: endotoxaemia, the cytokines and the acute-phase response. In order to study the effects of extreme exercise, we chose a long-distance triathlon $(3.8 \mathrm{~km}$ swimming, $185 \mathrm{~km}$ cycling and $42.2 \mathrm{~km}$ running) in Embrun, France. This triathlon is believed to be one of the most challenging world-wide. The conditions of this race are extreme (high temperatures, altitude, long duration), and thus the prevalence of GI symptoms and possibly endotoxaemia was expected to be high.

\section{METHODS}

\section{Subjects and protocol}

In total, 29 male triathletes and one female triathlete were recruited for the study. All subjects were instructed and informed about the procedures of the study, and signed a consent form. Subjects' age and weight was $33.0 \pm 6.0$ years and $72.3 \pm 7.3 \mathrm{~kg}$ respectively. The Ironman distance triathlon in Embrun (Embrunman) in France, held on 15th August 1996, was chosen because this is supposed to be one of the most challenging long-distance triathlons. After the swim $(3800 \mathrm{~m})$ in open water, athletes cycled a course of $185 \mathrm{~km}$ in the mountains (Alps) with an altitude difference of $3600 \mathrm{~m}$. Subsequently the athletes ran $42.2 \mathrm{~km}$, partly on unpaved roads. The temperature was $9.4^{\circ} \mathrm{C}$ in the morning at the start (6.00 hours), with a high of $32.1{ }^{\circ} \mathrm{C}$ around 14.00 hours. The water temperature was $18.6^{\circ} \mathrm{C}$ at the start.

\section{Questionnaire}

A questionnaire (20 items) was provided 2 or 3 days before the race containing questions regarding training background, performance level, experience, preparation and the use of supplements. A second questionnaire (96 items) was provided directly after the race, and athletes were asked to complete this within $2 \mathrm{~h}$ after finishing. This second questionnaire contained questions regarding the occurrence of GI symptoms during swimming, cycling and running, and in the $1 \mathrm{~h}$ after the race. In case 
subjects abandoned the race, questions were included to obtain the reason for abandoning.

\section{Body mass and fluid balance}

Weight was recorded on the day before the triathlon, $1 \mathrm{~h}$ before the start and immediately after the race. Subjects were carefully instructed to report fluid and solid food intake during the race as accurately as possible. Fluid intake was estimated from the reported beverage (and solid food) intake. Immediately after the race, athletes were also asked to write down as accurately as possible what beverages and solid food they had consumed during the race, and in what amounts. The nutritional composition of the dietary intake during the race was calculated through information from producers of particular products or from the Dutch Nutritional (NEVO) tables. Fluid loss was estimated from weight loss and corrected for fluid intake.

\section{Blood collection and analyses}

Blood samples were collected on the day before the race, immediately after the finish of the race, and $1 \mathrm{~h}, 2 \mathrm{~h}$ and 15-20 h after the finish. The blood was used for the measurement of LPS, anti-LPS, TNF- $\alpha$, IL-6, CRP and pre-albumin. At each time point three samples of $4.0 \mathrm{ml}$ of heparin-anticoagulated blood were collected (Endo Tube; Chromogenix AB, Mölndahl, Sweden), along with $5.0 \mathrm{ml}$ of non-anticoagulated blood. The tubes with the heparinized blood were immediately placed on melting ice. One was centrifuged at $180 \mathrm{~g}$ and $4{ }^{\circ} \mathrm{C}$ for $10 \mathrm{~min}$ to prepare platelet-rich plasma for the LPS assays. These samples were divided into two aliquots and stored at $-20^{\circ} \mathrm{C}$. The two other tubes were centrifuged at $3000 \mathrm{~g}$ and $4{ }^{\circ} \mathrm{C}$ for $10 \mathrm{~min}$ to prepare platelet-poor plasma for the TNF- $\alpha$ and IL- 6 assays. The platelet-poor plasma was divided into $500 \mu \mathrm{l}$ aliquots. The $5 \mathrm{ml}$ non-anticoagulated blood sample was allowed to clot for at least $30 \mathrm{~min}$ at ambient temperature to prepare serum, centrifuged at $3000 \mathrm{~g}$ at $4{ }^{\circ} \mathrm{C}$ for $10 \mathrm{~min}$, and aliquots of $500 \mu \mathrm{l}$ were stored at $-20^{\circ} \mathrm{C}$. The serum was used for the antiLPS, pre-albumin and CRP assays.

Blood was also collected from 20 healthy untrained male volunteers (mean age 38 years; range $20-55$ years) to determine reference ranges of anti-LPS, IL-6, prealbumin and CRP. The reference ranges were determined in male volunteers because 29 of the 30 athletes were also male. All results were corrected for fluid shifts.

\section{LPS}

LPS was assayed using chromogenic assays obtained from Boehringer Ingelheim Whittaker, Verviers, France (the $\beta$-glucan-insensitive LPS assay) and Chromogenix AM, Mölndal, Sweden (the more $\beta$-glucan-sensitive LPS assay), as described previously [26-28]. A $\beta$-glucansensitive LPS assay was used in addition to a $\beta$ glucan-insensitive LPS assay in order to detect the presence of fungi. $\beta$-Glucan is present in fungi and would therefore be detected with the $\beta$-glucan-sensitive assay, but not with the $\beta$-glucan-insensitive LPS assay. Also, there is controversy in the literature as to whether endotoxaemia does occur after exercise, and we therefore decided to use two assays from independent companies.

Briefly, the platelet-rich plasma samples were thawed for $5 \mathrm{~min}$ at $37^{\circ} \mathrm{C}$, diluted 10 -fold with pyrogen-free water and heated for $15 \mathrm{~min}$ at $75^{\circ} \mathrm{C}$ to remove inhibitory activity from the plasma. After cooling to room temperature for $1 \mathrm{~h}, 50 \mu \mathrm{l}$ aliquots were transferred to a microtitre plate. After incubation at $37^{\circ} \mathrm{C}$ with $50 \mu \mathrm{l}$ of LAL (Limulus amoebocyte lysate) reagent (Biowhittaker $30 \mathrm{~min}$; Chromogenix $12 \mathrm{~min}$ ) and the subsequent chromogenic substrate (Biowhittaker $6 \mathrm{~min}$; Chromogenix $8 \mathrm{~min}$ ), the reaction was stopped with acetic acid and the yellow colour read at $405 \mathrm{~nm}$. Readings were compared with a standard curve prepared in human platelet-rich plasma with the Escherichia coli 0111:B4 standard provided by the manufacturers according to the same procedure and prepared simultaneously with the test samples. With this standard, 1.2 endotoxin units $/ \mathrm{ml}$ corresponds to approx. $120 \mathrm{pg} / \mathrm{ml}$.

\section{$\lg G$ anti-LPS}

IgG anti-LPS was assayed by ELISA with reagents (Endocab) that were kindly provided by Chromogenix AB. Briefly, serum samples were thawed at room temperature and diluted 200 -fold in the sample buffer provided in the kit. Then $100 \mu \mathrm{l}$ of this diluted sample or standard was added to a microtitre plate, which had been precoated with a mixture of LPS by the manufacturer. After incubation at $37^{\circ} \mathrm{C}$ for $60 \mathrm{~min}$ to bind the anti-LPS antibodies in the serum to the plate, the plate was washed three times with wash buffer. Then $100 \mu$ l of an antibody to human IgG was added, which had been conjugated to alkaline phosphatase. After incubation for $60 \mathrm{~min}$ at $37^{\circ} \mathrm{C}$, the plate was washed three times with wash buffer and five times with distilled water. Then $100 \mu \mathrm{l}$ of a freshly prepared substrate solution of $800 \mu \mathrm{M} p$ nitrophenyl phosphate was added; the incubation was continued for $60 \mathrm{~min}$ at ambient temperature in the dark, and then the reaction was stopped by the addition of $50 \mu \mathrm{l}$ of $3 \mathrm{M} \mathrm{H}_{2} \mathrm{SO}_{4}$ and the absorbance was read at $405 \mathrm{~nm}$. Endocab is expressed in median units $/ \mathrm{ml}$, i.e. the median level observed in a group of 100 volunteers tested by the manufacturer.

\section{TNF- $\alpha$ and IL- 6}

In the assays for TNF- $\alpha$ and IL-6, Endo tube ET collection tubes were used to avoid any contamination with LPS and thus to avoid higher levels of TNF- $\alpha$ and IL-6 due to in vitro activation of blood cells. TNF- $\alpha$ and IL-6 were determined by ELISA (Pelikine Compact ${ }^{\circledR}$ TNF- $\alpha$ and IL- 6 ELISA kits; Central Laboratory of the Netherlands Red Cross Blood Transfusion Service). 
CRP

CRP was determined by nephelometry on an Hitachi 911 analyser (Boehringer Mannheim, Mannheim, Germany) with reagents and according to the instructions provided by this supplier.

\section{Pre-albumin}

Pre-albumin was determined by nephelometry on an auto-analyser (ARRAY; Beckman Instruments Inc., Breda, The Netherlands), with reagents and according to the instructions provided by this supplier.

Creatine kinase (CK)

CK was determined by spectrophotometry on an Hitachi 747 analyser (Boehringer Mannheim) with the $N$ acetylcysteine-activated $\mathrm{CK}$ reagent kit and according to the instructions provided by this supplier.

\section{Statistics}

GI symptoms were divided into two categories: severe symptoms and less severe symptoms. Severe symptoms included nausea, urge to vomit, vomiting, stomach ache and intestinal cramps. Nausea, stomach ache, intestinal cramps and urge to vomit were only registered as severe symptoms when a score of 5 or higher out of 10 was given. Less severe symptoms included eructation, flatulence, urge to defecate, heartburn and abdominal pressure (bloating). Nausea, stomach ache, intestinal cramps and urge to vomit were registered as non-severe symptoms when a score below 5 was given.

Symptoms reported during cycling and running were compared with LPS and anti-LPS concentrations, as well as with the parameters of the cytokine and acute-phase response, using a Spearman Rank Correlation test. GI complaints reported during swimming were ignored because it is unlikely that these complaints would be related to endotoxaemia.

A one-way analysis of variance was used to detect changes over time. In cases of a significance, the difference was located with a Tukey post-hoc test. To study differences in measured blood parameters between the triathletes and untrained healthy control subjects, an unpaired $t$-test was applied. In all cases the level of significance was set at $P<0.05$, and all results are expressed as means \pm S.E.M.

\section{RESULTS}

\section{Study group}

Because of incomplete data collection, the results from one subject were discarded. Four out of the remaining 29 participants abandoned the race $(14 \%)$. The reasons for abandoning varied among athletes. Two of them could not continue because of GI problems, and two abandoned
Table I GI and related complaints during the triathlon Nausea, stomach ache, intestinal cramps and urge to vomit were only registered when a score of 5 or higher (out of 10 ) was given.

\begin{tabular}{lrr}
\hline Complaint & $n$ & $\%$ \\
\hline Stomach problems & 9 & 31 \\
Nausea & 6 & 21 \\
Dizziness & 2 & 7 \\
Headache & 3 & 10 \\
Flatulence & 11 & 38 \\
Urge to urinate & 19 & 66 \\
Urge to defecate & 4 & 14 \\
Belching & 10 & 35 \\
Heartburn & 2 & 7 \\
Bloating & 7 & 24 \\
Stomach cramps & 3 & 10 \\
Intestinal cramps & 4 & 14 \\
Urge to vomit & 6 & 21 \\
Vomiting & 6 & 21 \\
Diarrhoea & 2 & 7 \\
Side ache left & 1 & 3 \\
Side ache right & 3 & 10 \\
Muscle cramps & 6 & 21 \\
Cold shivering & 3 & 10 \\
\hline
\end{tabular}

because of muscle cramping and muscle soreness or lower back problems.

\section{GI complaints}

The vast majority of the subjects $(93 \%)$ reported some GI symptoms, most of them being non-severe. The most frequently reported complaints were flatulence and eructation. There was also a relatively high prevalence of severe symptoms (Table 1$)$. Six subjects $(21 \%)$ reported an urge to vomit during either cycling or running, and these subjects also vomited. One athlete during cycling and one during running reported diarrhoea. Two athletes abandoned the race because of severe GI problems, including diarrhoea, stomach cramping, vomiting and nausea.

\section{Assays}

The mean LPS concentration, as measured with the $\beta$ glucan-insensitive assay, showed an increase immediately post-exercise, and this increase was more pronounced $1 \mathrm{~h}$ after the race (Figure 1). The highest measured value was $15.0 \mathrm{pg} / \mathrm{ml}$. If it is assumed that endotoxaemia is present at LPS concentrations of $>5.0 \mathrm{pg} / \mathrm{ml}[17,21]$ then, at $1 \mathrm{~h}$ after the race, $68 \%$ of the athletes had endotoxaemia. At $2 \mathrm{~h}$ after the race only $19 \%$ of the athletes had endotoxaemia, but this proportion was increased again $16 \mathrm{~h}$ after the race (79\%). With the $\beta$-glucan-sensitive assay a similar pattern in the LPS concentrations was observed, but the highest level of LPS-active material was measured immediately after the race. IgG anti-LPS levels had not 

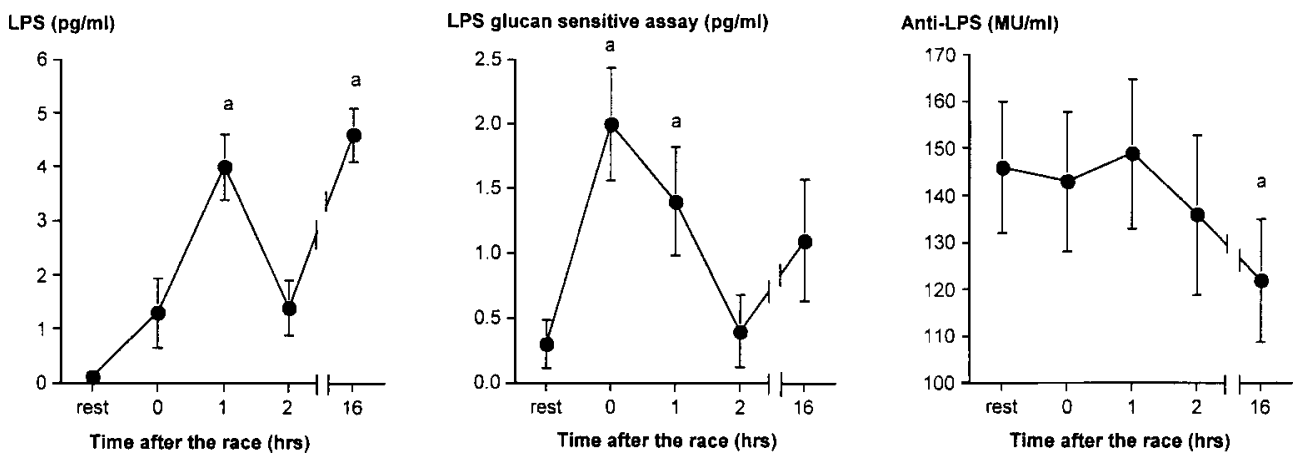

\section{Figure I LPS levels and IgG anti-LPS levels before and at several time points after the triathlon}

LPS levels were measured both with a $\beta$-glucan-insensitive assay (left panel) and with a more $\beta$-glucan-sensitive assay (middle panel). The right panel depicts antiLPS levels in median units $(\mathrm{MU}) / \mathrm{ml}$. Values are means \pm S.E.M. A significant elevation compared with the pre-race value is indicated by: ${ }^{\text {a }} P<0.05$.
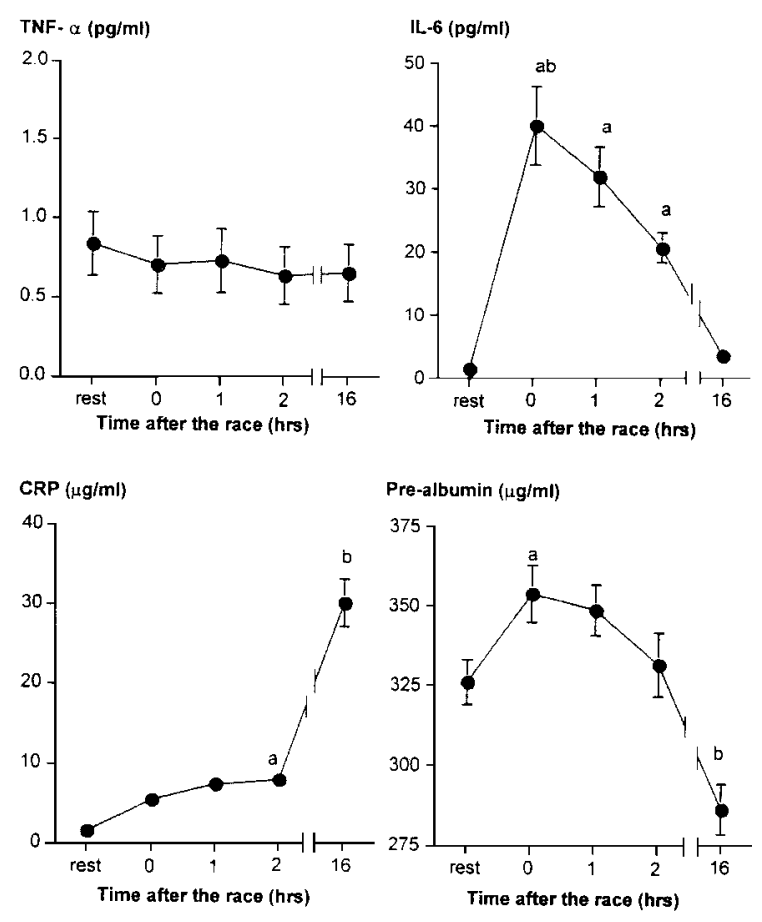

Figure 2 Concentrations of IL-6, TNF- $\alpha$, CRP and prealbumin before and at several time points after the triathlon CRP and pre-albumin represent positive and negative acute-phase proteins respectively. Values are means \pm S.E.M. Significant changes compared with prerace values are indicated by ${ }^{\mathrm{a}} P<0.05$; significant changes compared to $2 \mathrm{~h}$ after the race are indicated by ${ }^{\mathrm{b}} P<0.05$.

changed directly or $1 \mathrm{~h}$ after the race, but showed a tendency to decline after $2 \mathrm{~h}$. After $16 \mathrm{~h}$ anti-LPS had declined significantly compared with the levels at rest and during the first $2 \mathrm{~h}$ after completion of exercise.

The concentrations of TNF- $\alpha$, IL-6, CRP and prealbumin are presented in Figure 2. The TNF- $\alpha$ concentration was $0.84 \pm 0.20 \mathrm{pg} / \mathrm{ml}$ before the race, and this did not change significantly at any of the study periods. The IL-6 concentration showed a significant average 27 -fold increase immediately after the race, and then

Table 2 Correlations between changes in CRP, IL-6 and prealbumin levels and $\mathrm{GI}$ complaints

The presented values are Spearman rank correlation coefficients $\left(r_{s}\right)$; significance is indicated by: ${ }^{*} P<0.05 ;{ }^{* *} P<0.01$. The changes $(\Delta)$ in CRP, IL- 6 and prealbumin levels were expressed as the change for each athlete between the value at rest (before the race) and the value at the time of maximum response (for IL6 immediately after the race; for (RP and pre-albumin $16 \mathrm{~h}$ after the race).

\begin{tabular}{llll}
\hline & \multicolumn{2}{l}{$r_{s}$} & \\
\cline { 2 - 4 } GI complaint & $\Delta \mathrm{IL}-6$ & $\Delta \mathrm{CRP}$ & $\Delta$ Pre-albumin \\
\hline Nausea & 0.155 & 0.259 & 0.223 \\
Dizziness & 0.264 & 0.350 & $0.503^{*}$ \\
Intestinal cramps & 0.174 & $0.397^{*}$ & $0.533^{* *}$ \\
Vomiting & $0.268^{*}$ & 0.381 & 0.165 \\
Diarrhoea & $0.504^{*}$ & $0.51 \mathrm{I}^{*}$ & $0.529^{*}$ \\
\hline
\end{tabular}

decreased slowly. On the day after the race $(16 \mathrm{~h}), \mathrm{IL}-$ 6 had returned to pre-race levels. The CRP concentration was elevated $2 \mathrm{~h}$ after the race compared with at rest $(1.53 \pm 0.11 \mu \mathrm{g} / \mathrm{ml})$, and was increased on average by 20 fold $16 \mathrm{~h}$ after the race to a value of $30.2 \pm 3.0 \mu \mathrm{g} / \mathrm{ml}$. One subject had a CRP concentration of $62.4 \mu \mathrm{g} / \mathrm{ml}$. The prealbumin concentration was slightly elevated immediately after the race and started to decrease in the hour after the race. At $16 \mathrm{~h}$ after the race the pre-albumin concentration was significantly lower than the concentration on the day of the race.

Increases in LPS and IgG anti-LPS were not correlated with any of the GI symptoms reported during running and cycling (results not shown). The change in IL-6 concentration from rest to directly after the race showed a significant correlation with vomiting and diarrhoea during running (Table 2). Markers of the acute-phase response (CRP and pre-albumin) also showed a significant correlation with the incidence of diarrhoea during running. Additionally, these two markers of the acute-phase response were correlated with the score for intestinal cramps during running. The responses for the 
Table 3 Resting concentrations of IgG anti-LPS, IL-6, TNF- $\alpha$, CRP and pre-albumin in triathletes and untrained controls Values are means \pm S.E.M., with ranges given in parentheses. MU, median units.

\begin{tabular}{llll}
\hline & Controls & Triathletes & $P$-value \\
\hline IgG anti-LPS $(\mathrm{MU} / \mathrm{ml})$ & $242 \pm 28$ & $146 \pm 14$ & 0.0013 \\
& $(65-470)$ & $(15-288)$ & \\
$\mathrm{IL}-6(\mathrm{pg} / \mathrm{ml})$ & $1 . \mathrm{I} \pm 0.2$ & $1.5 \pm 0.3$ & 0.3444 \\
& $(0.7-6.5)$ & $(0.0-7.0)$ & \\
CRP $(\mu \mathrm{g} / \mathrm{ml})$ & $2.47 \pm 0.34$ & $1.53 \pm 0.1 \mathrm{I}$ & 0.0033 \\
& $(0.74-6.21)$ & $(0.54-3.61)$ & \\
Pre-albumin $(\mu \mathrm{g} / \mathrm{ml})$ & $322 \pm 15$ & $326 \pm 7$ & 0.8238 \\
& $(200-494)$ & $(239-418)$ & \\
\hline
\end{tabular}

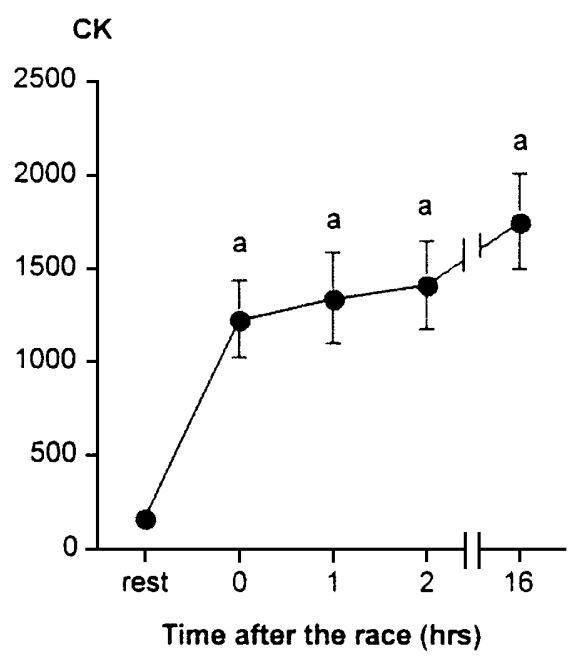

Figure 3 CK response after the triathlon

Values are means \pm S.E.M. Significant changes compared with the pre-race value are indicated by ${ }^{\text {a }} P<0.05$.

two athletes who abandoned the race because of GI problems were similar to those of athletes with few or no GI complaints.

There was no correlation between the highest LPS concentration and the highest IL-6 concentration in each athlete [Spearman rank correlation coefficient $\left(r_{\mathrm{s}}\right)$ 0.039; $P=0.84]$. However, there was a correlation, albeit weak, between the highest IL- 6 and CRP concentrations $\left(r_{\mathrm{s}}\right.$ $0.442 ; P=0.016)$ and between the LPS and CRP concentrations $\left(r_{\mathrm{s}} 0.389 ; P=0.037\right)$.

Reference values were obtained from healthy untrained control subjects for anti-LPS, IL-6, pre-albumin and CRP (Table 3). Compared with this control group, the athletes had lower concentrations of anti-LPS and CRP at rest (Table 3). No differences were observed in IL-6 and pre-albumin concentrations.

Plasma CK concentrations were significantly elevated after exercise, and continued to increase in the first $1 \mathrm{~h}$ after the race (Figure 3 ). This increase, however, was not correlated with changes in the IL-6 concentration $\left(r_{\mathrm{s}} 0.174 ; P=0.366\right)$. Similarly, no correlation was found between $\mathrm{CK}$ and changes in TNF- $\alpha$ concentration $\left(r_{\mathrm{s}}\right.$ $-0.139 ; P=0.473)$, between $\mathrm{CK}$ and changes in CRP concentration $\left(r_{\mathrm{s}} 0.363 ; P=0.053\right)$, or between CK and changes in pre-albumin concentration $\left(r_{\mathrm{s}} 0.244 ; P=\right.$ 0.220).

\section{DISCUSSION}

The majority of the athletes in the present study (93\%) reported GI symptoms, and two athletes had to abandon the race because of severe GI distress (vomiting and diarrhoea). Such GI problems are often reported by endurance athletes during long races, especially in the heat and when running is involved [12-14]. Several of those symptoms are also seen in patients with endotoxaemia, i.e. dizziness, nausea and vomiting during and after the race. Indeed, elevated LPS levels were detected after the race in many athletes $(68 \%$ immediately post-race and $79 \%$ after $16 \mathrm{~h}$ ). However, only mild endotoxaemia was observed in the athletes (i.e. LPS just above the $5 \mathrm{pg} / \mathrm{ml}$ threshold used to define endotoxaemia), the degree of endotoxaemia was not correlated with the incidence or the severity of the complaints, and there was no correlation between LPS and IL-6 concentrations, whereas the cytokine response (especially the IL-6 concentration) was correlated with severe complaints (diarrhoea and vomiting). It may then be questioned whether LPS does play a role in the occurrence of the GI complaints. However, the absence of a direct correlation between LPS and IL-6 concentrations is not surprising, and does not imply that these parameters are not related. For instance, intravenous injection of a bolus of LPS into human volunteers resulted in a very transient peak of LPS in the circulation, varying between 7 and $13 \mathrm{pg} / \mathrm{ml}$, but also resulted in maximal TNF- $\alpha$ levels of $68-1374 \mathrm{pg} / \mathrm{ml}$ and IL-6 levels of $72-2820 \mathrm{pg} / \mathrm{ml}$ [23]. A direct, linear correlation between LPS, TNF- $\alpha$ and IL- 6 concentrations is therefore unlikely to be obtained in vivo, but this does not exclude the possibility of a relationship between them.

The degree of endotoxaemia observed in the present study may seem mild, but if one considers the previous volunteer study [23], an LPS concentration of the same order (approx. $10 \mathrm{pg} / \mathrm{ml}$ ) and present very transiently gave rise to the cytokine responses mentioned above, i.e. fever, dizziness, leucocyte changes, etc. The finding of such mild endotoxaemia in these extreme conditions is seemingly in contrast with two other studies [16,18], which reported a high incidence of extreme endotoxaemia in athletes participating in a $90 \mathrm{~km}$ run (Comrades Marathon) and a long-distance triathlon respectively. In the study by Brocke-Utne et al. [16], $81 \%$ of the athletes had LPS levels above $100 \mathrm{pg} / \mathrm{ml}$, whereas in the present study the highest measured LPS level was $15 \mathrm{pg} / \mathrm{ml}$. One 
explanation for the discrepancy may be the fact that the athletes studied by Brocke-Utne et al. [16] were exhausted runners who had to abandon the race because of GI complaints, dehydration and heat shock, whereas in the present study $86 \%$ of the participants were able to finish the race. However, similar observations were made by Bosenberg et al. [18], who studied 18 triathletes and observed that plasma LPS concentrations rose from a mean of $81 \mathrm{ng} / \mathrm{ml}$ to $294 \mathrm{ng} / \mathrm{ml}$. It must be kept in mind, however, that the reported resting LPS concentrations in those studies were already higher than those observed in critically ill septic patients, which raises doubt about the validity of the results. Analytical differences are likely to be responsible for the discrepancies between the two previous studies $[16,18]$ and the present study. When an LPS assay similar to the one used in the present study was performed by Camus et al. [21], the results were in agreement with ours. In that study very mild endotoxaemia (between 5 and $14 \mathrm{pg} / \mathrm{ml}$ ) was observed after a marathon in eight out of 18 athletes, whereas one athlete had a high LPS level of $72 \mathrm{pg} / \mathrm{ml}$ [24].

The analysis of LPS in plasma is critically dependent upon several factors, which may be responsible for the discrepancies between the findings in the present study and those of Brocke-Utne et al. [16] and Bosenberg et al. [18]. LPS is usually determined with the LAL assay $[27,28]$. This assay is based on the property of LPS to activate the clotting cascade which is present in the circulating cell (amoebocyte) of Limulus polyphemus, the horseshoe crab. With this assay it is possible to detect very low levels of LPS in plasma $(3 \mathrm{pg} / \mathrm{ml}$ or 0.036 endotoxin units $/ \mathrm{ml}$ ), which is essential because endotoxaemia in humans is considered to be present at LPS concentrations above $5 \mathrm{pg} / \mathrm{ml}$ [17]. A first critical point is that plasma contains inhibitory substances that have to be removed before the LPS assay. A dilution and heating procedure is usually the method of choice [29]. Details of the method to remove the inhibitory activity in plasma are not always indicated $[16,18]$. Secondly, the reference ranges in the other studies $[16,18]$ are rather high, i.e. between 64 and $100 \mathrm{pg} / \mathrm{ml}$, and would therefore be within the range observed in septic patients using other assays. Thirdly, the LAL reagent not only may react to LPS, but may also be sensitive to $\beta$-glucan. $\beta$-Glucan is present in fungi, and can be found in the membranes used in kidney dialysis and cardiobypass apparatus [29]. In the present study both a $\beta$-glucan-insensitive and a more $\beta$ glucan-sensitive LPS assay were used. Immediately after the race, the $\beta$-glucan-sensitive assay gave higher levels of LPS than the $\beta$-glucan-insensitive assay. This could indicate that fungal material, also likely to originate from the intestine, is present in the circulation at that time. It is unclear whether the LAL in the other two studies $[16,18]$ was glucan sensitive, but the two assays we used, from different companies, both indicated low levels of endotoxaemia.
Another method for investigating whether LPS has appeared in the circulation is to measure the plasma antiLPS concentration. In a study in racehorses, the $\operatorname{IgG}$ anti-LPS concentration was significantly reduced after a race [19]. Also, both the pre- and post-race IgG anti-LPS levels were lower than the values measured in untrained horses, which could indicate that training and competition lead to leakage of LPS into the circulation and a subsequent increase in specific antibody production [18]. Similarly, serum IgG anti-LPS concentrations were negatively correlated with the LPS concentration in the circulation in long-distance runners [16]. We observed $40 \%$ lower IgG anti-LPS levels in our trained subjects compared with untrained controls, which may also be due to some LPS leakage during training sessions in the weeks preceding the race. The observed decrease in $\mathrm{IgG}$ anti-LPS at $16 \mathrm{~h}$ after the triathlon suggests that there is a continuous leakage of LPS into the circulation in the first few hours after this extreme exercise.

Blood monocytes and tissue macrophages secrete several cytokines, such as TNF- $\alpha$ and IL- 6 , upon activation by LPS [30]. In the present study the TNF- $\alpha$ concentration did not change and was barely detectable above the lower detection limit of the assay $(0.5 \mathrm{pg} / \mathrm{ml})$, which is in agreement with some [31,32], but not all [24], previous studies. Northoff and Berg [31] and Rohde et al. [32] were unable to detect TNF- $\alpha$ in subjects on completion of a marathon and a triathlon respectively. The finding that TNF- $\alpha$ levels were low (i.e. just above the detection limit) and were not observed to increase is not surprising if one considers the much more serious condition of sepsis. In studies involving 97-146 patients with sepsis, only $4-54 \%$ of the patients had detectable levels of TNF- $\alpha$ in the circulation [33]. This may be due to the rapid clearance of TNF- $\alpha$ from the circulation [33], and the sensitivity of the assays in use at the time. Our findings are in contrast with those of Camus et al. [21], who reported a 2 -fold increase in TNF- $\alpha$ levels following a marathon, but the initial values of $10 \mathrm{pg} / \mathrm{ml}$ reported before the race make these data difficult to interpret.

Increased IL-6 levels were demonstrated in 28 of the 29 athletes in the present study, which confirms observations by other investigators after various exercise conditions [34], including a marathon [24]. This may, at least partly, be due to the endotoxaemia occurring during and after the triathlon, but the possibility cannot be excluded that the elevated IL-6 levels were also partly due to the exercise itself or to muscle damage. Bruunsgaard et al. [35] recently showed that IL-6 concentrations were significantly increased after $2 \mathrm{~h}$ of eccentric exercise, but not after $2 \mathrm{~h}$ of concentric exercise, and that the IL-6 concentration was significantly correlated with the $\mathrm{CK}$ concentration as a parameter of muscle damage. The athletes in the present study encountered a fair amount of downhill running and thus eccentric exercise. However, in the present study we could not find a correlation 
between the cytokine/acute-phase responses and plasma CK.

IL-6 is one of the main stimuli of the acute-phase reaction. CRP, a participant of the positive acutephase reaction, and pre-albumin, representing the negative acute-phase reaction, were markedly increased and decreased respectively in the samples collected $16 \mathrm{~h}$ after the race. Also, a positive correlation was obtained between the maximum IL-6 and CRP concentrations $\left(r_{\mathrm{s}}\right.$ 0.442; $P=0.016)$. Elevations of positive acute-phase proteins have been reported by others [36-39]. Dufaux et al. [36] and Liesen et al. [37] reported 6-fold increases in CRP 1 day after a $2 \mathrm{~h}$ or a $3 \mathrm{~h}$ run respectively, while a peak may be observed $24 \mathrm{~h}$ after strenuous exercise [39]. Castell et al. [38] reported a 4-fold increase in CRP levels $16 \mathrm{~h}$ after a marathon. These results seem to be in agreement with those of the present study, in which we found CRP to be increased 20-fold and pre-albumin to be decreased by $12 \% 16 \mathrm{~h}$ after the race.

In conclusion, mild systemic endotoxaemia was observed in some athletes in the hours after strenuous exercise. Also, anti-LPS levels were significantly decreased $16 \mathrm{~h}$ after exercise, suggesting that there was portal vein endotoxaemia during and after exercise. There was no linear correlation between the extent of systemic endotoxaemia and the severity of GI complaints or the IL-6 response. This suggests that systemic endotoxaemia is not a direct cause of GI complaints, but the absence of a correlation does not necessarily exclude a relationship between these parameters. There was a clear cytokine response immediately after exercise and a clear acutephase response on the day after exercise, and both of these were positively correlated with some of the severe GI complaints (e.g. diarrhoea, vomiting) during exercise. As both responses may, at least partly, have been due to the systemic and portal vein endotoxaemia, we conclude that the gut barrier function for bacterial endotoxins and potentially also for fungal $\beta$-glucans may be lost during severe prolonged exercise, and this may lead to GI complaints. However, the possibilty cannot be excluded that other exercise-induced processes, e.g. muscle damage, also play a role in cytokine and acute-phase activation.

\section{ACKNOWLEDGMENTS}

We gratefully acknowledge Chromogenix AB (Mölndal, Sweden) for provision of the reagents for the anti-LPS assay, and Quest International (Naarden, The Netherlands) for partial funding of this study. We also thank Mr. Gerald Iacono, the organizer of the Embrunman, for his kind co-operation and help, and Dr. C. Marble, head of the medical staff, for help and medical assistance. Also very much appreciated were help in sample collection from Dr. Bret Goodpaster, sample collection and preparation by Mr. Raymond Vet, the excellent analytical assistance of Ms. Marianne Schaap, Ms. Margo van Schie and Ms. Marja Kersbergen, and help in data analysis from Ms. Evelijn Zeijdner. Lastly, we thank Ms. Eva Kovacs, Ms. Regina Schmahl and Mr. Benoit Marchal for the excellent translation of the questionnaires in Italian, German and French.

\section{REFERENCES}

1 Bradley, S. E. (1949) Variations in hepatic blood flow in man during health and disease. N. Engl. J. Med. 240, 456-461

2 Rowell, L. B., Blackmon, J. R. and Bruce, R. A. (1964) Indocyanine green clearance and estimated hepatic blood flow during mild to maximal exercise in upright man. J. Clin. Invest. 43, 1677-1690

3 Clausen, J. P. (1977) Effect of physical training on cardiovascular adjustments to exercise in man. Physiol. Rev. 57, 779-815

4 Rowell, L. B., O’Leary, D. S. and Kellogg, D. L. (1996) Integration of cardiovascular control systems in dynamic exercise. Handb. Physiol. Sect. 12 Exercise Regul. Integr. Mult. Syst. 770-838

5 Williams, J. H., Mager, M. and Jaconson, E. D. (1962) Relationship of mesenteric blood flow to intestinal absorption of carbohydrates. 63, 853-863

6 Haglund, U. (1994) Gut ischaemia. Gut 35, S73-S76

7 Van Deventer, S. J. H. and Gouma, D. (1994) Bacterial translocation and endotoxin transmigration in intestinal ischaemia and reperfusion. Curr. Opin. Anaesthiol. 7, 126-130

8 Van Leeuwen, P. A. M., Boermeester, M. A., Houdijk, A. P. J. et al. (1994) Clinical significance of translocation. Gut 35 (suppl. 1), S28-S34

9 Brouns, F., Saris, W. H. M. and Rehrer, N. J. (1987) Abdominal complaints and gastrointestinal function during long-lasting exercise. Int. J. Sports Med. 8, 175-189

10 Rehrer, N. J., Brouns, F., Beckers, E. J. et al. (1992) Physiological changes and gastro-intestinal symptoms as a result of ultra-endurance running. Eur. J. Appl. Physiol. 64, 1-8

11 Rehrer, N. J., Janssen, G. M. E., Brouns, F. and Saris, W. H. M. (1989) Fluid intake and gastrointestinal problems in runners competing in a $25-\mathrm{km}$ race and a marathon. Int. J. Sports Med. 10, S22-S25

12 Keeffe, E. B., Lowe, D. K., Goss, J. R. and Wayne, R. (1984) Gastrointestinal symptoms of marathon runners. West. J. Med. 141, 481-484

13 Riddoch, C. and Trinick, T. (1988) Gastrointestinal disturbances in marathon runners. Br. J. Sports Med. 22, 71-74

14 Sullivan, S. N. (1981) The gastrointestinal symptoms of running. N. Engl. J. Med. 304, 915

15 Øktedalen, O., Lunde, O. C., Opstad, P. K., Aabakken, L. and Kvernebo, K. (1992) Changes in gastro-intestinal mucose after long-distance running. Scand. J. Gastroenterol. 27, 270-274

16 Brock-Utne, J. G., Gaffin, S. L., Wells, M. T. et al. (1988) Endotoxaemia in exhausted runners after a long distance race. S. Afr. Med. J. 73, 533-536

17 Van Deventer, S. J. H., Buller, H. R., ten Cate, J. W., Sturk, A. and Pauw, W. (1988) Endotoxaemia: an early predictor of septicaemia in febrile patients. Lancet $\mathbf{i}$, 605-608

18 Bosenberg, A. T., Brock-Utne, J. G., Gaffin, S. L., Wells, M. T. B. and Blake, G. T. W. (1988) Strenuous exercise causes systemic endotoxemia. J. Appl. Physiol. 65, 106-108

19 Baker, B., Gaffin, S. L., Wells, B. C. and Brock-Utne, J. G. (1988) Endotoxemia in race horses following exertion. J. S. Afr. Vet. Assoc. 59, 63-66

20 Moore, G. E., Holbein, M. E. and Knochel, J. P. (1995) Exercise-associated collapse in cyclists is unrelated to endotoxemia. Med. Sci. Sports Med. 27, 1238-1242 
21 Camus, G., Poortmans, J., Nys, M. et al. (1997) Mild endotoxaemia and the inflammatory response induced by a marathon race. Clin. Sci. 92, 415-422

22 Beutler, B. (1989) Cachectin in tissue injury, shock and related states. Crit. Care Clin. 5, 353-367

23 Van Deventer, S. J. H., Büller, H. R., ten Cate, J. W., Aarden, L. A., Hack, C. E. and Sturk, A. (1990) Experimental endotoxemia in humans: analysis of cytokine release and coagulation, fibrinolytic and complement pathways. Blood 76, 2520-2526

24 Darlington, G. J., Wilson, D. R. and Lachman, L. B. (1986) Monocyte-conditioned medium, interleukin-1, and tumor necrosis factor stimulate the acute phase response in human hepatoma cells in vitro. J. Cell Biol. 103, 787-793

25 Gauldie, J., Richards, C., Harnish, D., Landsdorp, P. and Baumann, H. (1987) Interferon $b_{2} / B$-cells stimulatory factor type 2 shares identity with monocyte-derived hepatocyte-stimulating factor and regulates the acute phase response in liver cells. Proc. Natl. Acad. Sci. U.S.A. 84, 7251-7255

26 Roslansky, P. F. and Novitsky, T. J. (1991) Sensitivity of Limulus amoebocyte lysate (LAL) to LAL-reactive glucans. J. Clin. Microbiol. 29, 2477-2483

27 Sturk, A., Joop, K., ten Cate, J. W. and Thomas, L. L. M. (1985) Optimalization of a chromogenic assay for endotoxin in blood. Prog. Clin. Biol. Res. 189, 117-137

28 Sturk, A., Janssen, G. M., Muylaert, F. R., Joop, K. and ten Cate, J. W. (1987) Endotoxin testing in blood. Prog. Clin. Biol. Res. 231, 371-385

29 Obayashi, T., Tamura, H., Tanaka, S., Ohki, M., Takahashi, S. and Kawai, T. (1986) Endotoxin-inactivating activity in normal and pathological human blood samples. Infect. Immun. 53, 294-297
30 Fong, Y., Moldawer, L. L., Marano, M. et al. (1989) Endotoxemia elicits increased circulating beta 2-IFN/IL-6 in man. J. Immunol. 142, 2321-2324

31 Northoff, H. and Berg, A. (1991) Immunological mediators as parameters of the reaction to strenuous exercise. Int. J. Sports Med. 12, S9-S15

32 Rohde, T., MacLean, D. A., Hartkopp, A. and Pedersen, B. K. (1996) The immune system and serum glutamine during a triathlon. Eur. J. Appl. Physiol. 74, 428-434

33 Hack, C. E., Aarden, L. A. and Thijs, L. G. (1997) Role of cytokinesis in sepsis. Adv. Immunol. 66, 101-195

34 Northoff, H., Weinstock, C. and Berg, A. (1994) The cytokine response to strenuous exercise. Int. J. Sports Med. $15,167-171$

35 Bruunsgaard, H., Galbo, H., Halkjaer-Kristiansen, J., MacLean, D. A. and Pedersen, B. K. (1997) Exerciseinduced increase in serum interleukin- 6 in humans is related to muscle damage. J. Physiol. (London) 499, 833-841

36 Dufaux, B., Order, U., Geyer, H. and Hollmann, W. (1984) C-reactive protein serum concentrations in welltrained athletes. Int. J. Sports Med. 5, 102-106

37 Liesen, H., Dufaux, B. and Hollmann, W. (1977) Modifications of serum glycoproteins the day following a prolonged physical exercise and the influence of physical training. Eur. J. Appl. Physiol. 37, 243-254

38 Castell, L. M., Poortmans, J. R., Leclercq, R., Brasseur, M., Duchateau, J. and Newsholme, E. A. (1997) Some aspects of the acute phase response after a marathon race, and effect of glutamine supplementation. Eur. J. Appl. Physiol. $75,47-53$

39 Weight, L. M., Alexander, D. and Jacobs, P. (1991) Strenuous exercise, analogous to the acute-phase response? Clin. Sci. 81, 677-683

Received 20 August 1999; accepted 14 September 1999 